
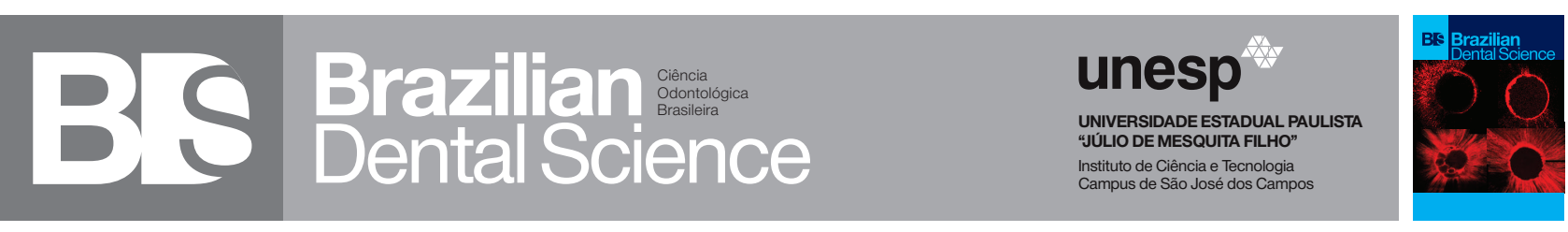

\title{
Efficacy of diode laser and sonic agitation of Chlorhexidine and Silver-nanoparticles in infected root canals
}

\author{
Eficácia do laser de diodo e agitação sônica de clorexidina e nanopartículas de prata em canais radiculares infectados
}

Latifa Mohamed ABDELGAWAD ${ }^{1}$, Niven ASMAIL ${ }^{1}$, Somia Abdel LATIF ${ }^{2}$, Ali Mohamed SAAFAN ${ }^{1}$

1 - Medical Laser Applications Department - National Institute of Laser Enhanced Sciences - Cairo University - Cairo - Egypt.

2 - Microbiology and Molecular Biology Department - Faculty of Medicine - Cairo University - Cairo - Egypt.

\section{ABSTRACT}

Objective: To assess the efficacy of agitation of chlorohexidine (CHX) and Silver nanoparticles "AgNps" with 810nm diode laser or sonic endoactivator compared to side -vented needle on infected root canals with Enterococcus "E" Faecalis biofilms. Material and Methods: Sixty-five extracted human premolars with single oval canals were instrumented by protaper system up to F3. Biofilms of $E$. faecalis were generated based on a previously established protocol. Two teeth were used to check the biofilm formation, then the remaining Teeth were randomly divided into three equal experimental groups according to agitation techniques used: group 1 (810 nm diode laser with 1 watt), group 2 (sonic endoactivator) and group 3 (Side vented needle). Each group was further divided into three equal subgroups according to the irrigant solution into; subgroup A: chlorohexidine, subgroup B: silver nanoparticles and subgroup C: distilled water: Confocal laser scanning microscopy "CLSM" was used to assess bacterial viability. Data were analyzed by appropriate statistical analyses with $\mathrm{P}=0.05$. Results: Regarding the activation method, all groups had a significantly high percentage of dead bacteria $(P<0.05)$. However, Laser was significantly the highest and Endoactivator the least $(\mathrm{P}<=0.001)$. Diode laser agitation of AgNps irrigant showed the highest reduction percentage of bacteria $(78.1 \%)$ with a significant difference with both CHX and water irrigation, Conclusion: Under the condition of the present study; results reinforced that laser activation is a useful adjunct, $810 \mathrm{~nm}$ diode laser agitation of AgNps or chlorhexidine was more effective in disinfection of oval root canals than endoactivator and side vented needle techniques.

\section{KEYWORDS}

Dentinal infection; Silver-nanoparticles; chlorohexidine; agitation; Diode Laser; Sonic endoactivator.

\section{RESUMO}

Objetivo: Avaliar a eficácia da agitação de clorohexidina (CHX) e nanopartículas de prata (AgNps), com laser de diodo de $810 \mathrm{~nm}$ ou endoativador sônico, em comparação à agulha de ventilação lateral, em canais radiculares infectados com biofilmes de Enterococcus "E"; Faecalis. Material eMétodos: Sessenta ecinco pré-molareshumanos com um único canal oval, extraídos, foram instrumentados pelo sistema protaper até F3. Os biofilmes de E. faecalis foram gerados com base em um protocolo previamente estabelecido. Foram utilizados dois dentes para verificar a formação do biofilme, e os dentes restantes foram divididos aleatoriamente em três grupos experimentais iguais, de acordo com as técnicas de agitação utilizadas: grupo 1 (laser de diodo $810 \mathrm{~nm}$ com 1 watt), grupo 2 (endoativador sônico) e grupo 3 (Agulha com ventilação lateral). Cada grupo foi dividido em três subgrupos iguais, de acordo com a solução irrigante; subgrupo A: clorohexidina, subgrupo B: nanopartículas de prata e subgrupo C: água destilada: A microscopia confocal de varredura a laser foi usada para avaliar a viabilidade bacteriana. Os dados foram analisados por análises estatísticas apropriadas com $\mathrm{P}=0,05$. Resultados: Em relação ao método de ativação, todos osgrupos apresentaram percentual significativamente alto de bactérias mortas $(\mathrm{P}<0.05)$. No entanto, para o laser foi significativamente o mais alto e, para oendoativador, o menos alto $(\mathrm{P}<=0.001)$. A agitação com laser de diodo doirrigante AgNps apresentou a maior porcentagem de redução de bactérias $(78,1 \%)$, com diferença significativa tanto para irrigação com CHX quanto comágua. Conclusão: Sob as condições do presente estudo; os resultadosreforçaram que a ativação a laser é um complemento útil, a agitação por laserde diodo de $810 \mathrm{~nm}$ de AgNps ou clorexidina foi mais eficaz na desinfecção dos canais radiculares ovais do que as técnicas de endoativador e agulha com ventilação lateral.

\section{PALAVRAS-CHAVE}

Infecção dentinária; Nanopartículas de prata; clorohexidina, bagitação; Laser de Diodo; endoativador sônico. 


\section{INTRODUCTION}

$\mathrm{O}$ ne of the main challenges facing the dentists in the endodontic steps is how to totally disinfect the root canal [1]. E faecalis is the most prominent microorganism involved in persistent infections after root canal therapy. E. faecalis has the ability to penetrate the dentinal tubules and cementum. It can survive in biofilm form at anatomical complexities of root canal system, over the foreign bodies like gutta-percha or other obturating materials extending into periapical tissues and can survive for prolonged periods under nutrientdepleted conditions [2].

Trying to overcome the challenge compulsory by the presence of biofilm and reach complete disinfection or significant bacterial reduction in the root canals, many irrigants have been indicated during endodontic treatment. Chlorhexidine gluconate $(\mathrm{CHX})$ at $2 \%$ is one of the most commonly used irrigants and considered as an effective antimicrobial agent. It has many properties; broad-spectrum, substantively (extended outstanding activity) and a relative absence of toxicity that recommend it to be used as an endodontic irrigant [3, 4].

Silver nanoparticles (AgNps) have gained popularity because of their unique ability to penetrate tissues, interact with bacteria, exhibit potent antimicrobial activity and biocompatibility [5].

The agitation of irrigating solutions with the laser has become common [6]. Researchers examined many laser systems to attain complete disinfection of root canal system and the adjacent dentinal tubules and yet there is still argument about which is the most powerful laser system in regards to providing a sterilized root canal system. The high bactericidal effect of diode laser has been reported in multiple studies [7]. Therefore, due to the bactericidal effect of diode laser and its low cost compared to other commonly used laser systems in endodontic, it can be used in agitation of the irrigation during the mechanical debridement procedures [8].

The Endoactivator System "EA" is a sonically driven irrigant activation system planned to produce dynamic fluid agitation inside the canal that has been shown to improve the effectiveness of irrigation better than the traditional syringe irrigation [9]. So the present study highlighted the effect of 810 $\mathrm{nm}$ diode laser and sonic agitation on two types of irrigants; [chlorohexidine (CHX) and silver nanoparticles (AgNps)] applied in root canals.

\section{MATERIAL AND METHODS}

This research was approved by the Ethics Committee of National Institute of Laser Enhanced Sciences (NILES), Cairo University, Egypt (CU/NILES/30/19). Also this study was done in the microbiology and molecular biology department, faculty of medicine, Cairo University.

\section{Selection and Mechanical preparation of samples}

Sixty -five extracted human premolars with single oval canal and fully formed apices were selected from hundred extracted teeth for periodontal reasons. Each root was digitally radiographed using RVG 6200 digital sensor (Carestream, Rochester, New York, United States) and measured by its software to select canals with ovality ratio more than 2.5 . The crowns were sectioned such that roots were standardized to $12+2 \mathrm{~mm}$ and stored in labeled vials at $100 \%$ humidity.

Preparation was performed using the ProTaper system (Dentsply-Maillefer, Ballaigues, Switzerland), following the sequence $\mathrm{S} 1, \mathrm{~S} 2, \mathrm{~F} 1, \mathrm{~F} 2$, and F3). Using $\mathrm{X}-$ smart motor at $300 \mathrm{rpm} / 2$. Ncm. (Dentsply, 
Switzerland) [10]. At every instrument change, the canals were irrigated with $5 \mathrm{ml}$ $2.5 \%$ sodium hypochlorite "NaOCl" solution (Clorox, Nobelwax Factories for chemicals, Egypt) using $5 \mathrm{ml}$-syringe with $30-\mathrm{G}$ sidevented needle (Canal Clean, Biodent, Co, Ltd, Pagu City, Korea) which inserted $2 \mathrm{~mm}$ short of working length.

\section{Final irrigation and sterilization of the samples}

Final irrigation was performed with $5 \mathrm{ml}$ 15\% Ethylenediaminetetraacetic acid "EDTA" (Endo-Solution, Cerkamed, Stalowa Wola, Polska) for $3 \mathrm{~min}$ and $5 \mathrm{ml} \mathrm{NaOCl}$ for $3 \mathrm{~min}$ to remove the smear layer, and then the canal was irrigated with $10 \mathrm{ml}$ of physiological saline solution to remove the EDTA. Finally, the teeth were sterilized in the autoclave at $121^{\circ} \mathrm{C}$ for $30 \mathrm{~min}$.

\section{Inoculation and incubation of the teeth with $\mathrm{E}$ faecalis}

Using a sterile micropipette, twenty microliters of $\mathrm{E}$.faecalis suspension (matching McFarland's turbidity of tube no 0.5 ) was syringed into each root canal. Each inoculated root was kept in separate sterile test tube with caps in a rack. Then incubated at $37^{\circ} \mathrm{C}$ for 7 days, to allow the proliferation of microorganisms, and their further penetration into the dentinal tubules and formation of biofilms.

\section{Classification of the samples:}

Two teeth were used to check the biofilm formation, then the remaining teeth (63) were randomly divided into three equal experimental groups according to agitation techniques used: group 1 (810 nm diode laser with 1 watt), group 2 (sonic endoactivator) and group 3 (Side vented needle). Each group was further equally divided into three subgroups according to the irrigant solution into; subgroup A: chlorohexidine, subgroup B: silver nanoparticles and subgroup C: distilled water:

The agitation mechanisms in the three groups were as a follow:

\section{Group 1 (diode Laser)}

Agitation was done with $810 \mathrm{~nm}$ Diode laser with continuous mode and output power 1 watt (Zolar lasers, Canada) which delivered into 200 um flexible plain endodontic fiber. The fiber was inserted parallel to root canal wall and used with helicoidally movement in apical-coronal directions. Agitation was done for 10 seconds to $1 \mathrm{ml}$ irrigant. The sequence was repeated 5 times, giving $5 \mathrm{ml}$ total volume and $50 \mathrm{sec}$ total agitations.

\section{Group 2 (Sonic endoactivator)}

In this group agitation was done by Sonic endoactivator device (Dentsply, Tulsa) with red polymer tip \# 25/0.04 at speed 10000 $\mathrm{rpm}$. The samples in this group were irrigated with $5 \mathrm{ml}$ of an irrigating solution, where each $1 \mathrm{ml}$ of the irrigant was followed by 10 seconds of sonic agitation [11].

\section{Group 3 (side -vented needle)}

Side vented needle delivered $5 \mathrm{ml}$ irrigant during moving slowly up and down along canal length. All agitations were performed at $2 \mathrm{~mm}$ away from the working length.

\section{Confocal laser scanning microscopy (CLSM) examination}

Sixty -five roots were sectioned for detecting viable and nonviable bacteria on root canal walls. Roots were set in blocks of fast setting acrylic resin and two lines were drawn with a marker on the exposed part of the root, one buccal and one palatal for vertically sectioning into two halves, approximately parallel to the tooth axis, utilizing the microtome saw. A sample from each sectioned root was taken for scanning. Each sample was stained by both Acridine 
orange (AO) and Propidium iodide (PI) dyes separately, just before the CLSM examination. Zeiss LSM 710 confocal microscope (Carl Zeiss, Germany) was used with $40 \mathrm{x}$ objectives for scanning. Three random areas of the middle third of the root canal were scanned with a 2-mm step size by the CLSM. For each image the median intensity of green and red bacteria were calculated by the soft-ware (green for live and red for dead bacteria), this number was tabulated and statistically analyzed.

\section{Data presentation and analysis}

To identify the effect of activation protocols on bacterial reduction (dead cell \%) in each irrigation protocol, one-way ANOVA was applied. Bonferroni's correction for multiple testing was used in one-way analysis of variance. $\mathrm{P}=0.05$ for the analyses. Twoway ANOVA was performed to weigh the effect of the irrigation protocol and activation method as the two independent variables on the outcome (percentage of dead cells. Data was analyzed using IBM SPSS advanced statistics (Statistical Package for Social Sciences), version 21 (SPSS Inc., Chicago, IL).

\section{RESULTS}

The data obtained from the CLSM are tabulated (TableI). Figure 1 shows a homogenous penetration of $\mathrm{E}$. faecalis deep into the dentinal tubules of the root canal. figure 2 shows biofilm destruction within the root canal lumen for all groups. Regarding the activation method, all groups had a significantly high percentage of dead bacteria $(\mathrm{P}<0.05)$. However, Laser was significantly the highest and Endoactivator the least $(\mathrm{P}<=0.001)$.

Regarding the irrigant type; AgNps activated with diode laser had the highest percentage of dead bacteria (78.1\%) followed by needle agitation (76.47\%) then sonic (72.94\%). Without significant difference ( $\mathrm{p}>$ $0.05)$
In chlorhexidine subgroup, the high percentage of dead bacteria was in laser group (71.81\%) followed by needle group (70.18\%) then sonic group (68.99) Without significant difference $(p>0.05)$. while distilled water subgroup showed high percentage of bacterial reduction in laser group (71.46\%) followed by sonic $(62.7847 \%)$ then needle group $(60.6 \%)$ with significant difference between laser and sonic and laser with needle $(p<0.05)$ while there was no significant difference between sonic and needle ( $\mathrm{p}>0.05)$.

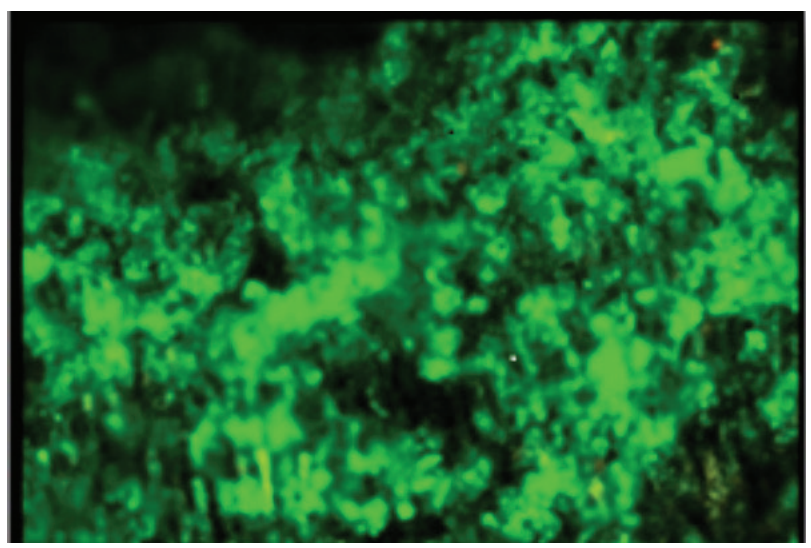

Figure 1- Representative Confocal laser scanning microscope (CLSM) image of E. faecalis within dentinal tubules
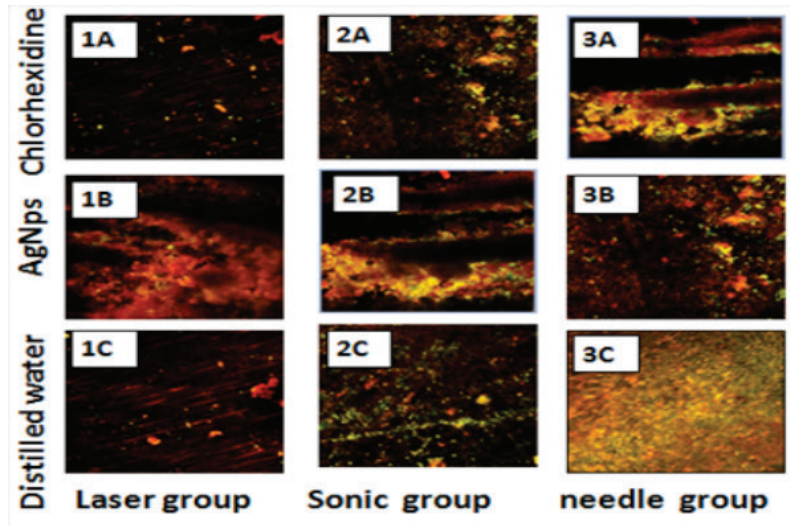

Figure 2 - Representative confocal laser scanning microscope (CLSM) images in Laser, sonic and needle activation groups with chlorhexidine or AgNps or distilled water irrigant showing the distribution of live (green fluorescence) and dead bacteria (red fluorescence) within the dentinal tubules. (1A) $\mathrm{CHX}$ activated by laser, (2A) $\mathrm{CHX}$ activated by sonic. (3A) $\mathrm{CHX}$ activated by needle, (1B) AgNps activated by Laser, (2B) AgNps activated by sonic (3B)) AgNps activated by needle, (1C) Distilled water activated by laser, (2C) Distilled water activated by sonic and (3C) Distilled water activated by needle. 
Table I - percent of apparently dead bacterial cells in the biofilm within the dentinal tubules, assessed by confocal laser microscopy after three different activation techniques with three different irrigant.

\begin{tabular}{|ccccc|}
\hline Group & Subgroup & Mean \% & Std. Deviation & P value \\
\hline \multirow{4}{*}{ Laser*\# } & CHX & $71.8143^{\mathrm{a}}$ & 4.03276 & \\
& AgNps & $78.0514^{\mathrm{c}}$ & 3.94723 & 0.018 \\
& $\mathrm{H} 2 \mathrm{O}$ & 71.4565 & 4.82094 & \\
& $\mathrm{CHX}$ & $68.9947^{\mathrm{c}}$ & 2.33525 & \\
Sonic & $\mathrm{AgNps}$ & $72.9405^{\mathrm{b}}$ & 3.58203 & 0.002 \\
& $\mathrm{H} 2 \mathrm{O}$ & $62.7847^{\mathrm{d}}$ & 7.55672 & \\
& $\mathrm{CHX}$ & $70.1782^{\mathrm{ab}}$ & 3.73252 & \\
\hline \multirow{2}{*}{ Needle } & $\mathrm{AgNpS}$ & $76.470 \mathrm{f}^{\mathrm{c}}$ & 6.55219 & 0.044 \\
& $\mathrm{H} 20$ & 60.6 & 3.2501 & \\
\hline & & & & \\
\hline
\end{tabular}

$\left.{ }^{*}\right)$ means significant between laser and sonic in $\mathrm{H} 2 \mathrm{O}$ irrigant (\#) means significant between laser and needle in $\mathrm{H} 2 \mathrm{O}$ irrigant (a) Means significant $\mathrm{CHX}$ and AgNps within the same group

(b) Means significant between $\mathrm{CHX}$ and $\mathrm{H} 2 \mathrm{O}$ within the same group

(c) Means significant between AgNps and H2o within the same group.

\section{DISCUSSION}

The main goal of endodontic treatment is the complete disinfection of the root canal system; however, it is difficult due to complex anatomy of the root canal system and biofilm mediated infection. E. faecalis was chosen because it is generally believed that it is one of the most resistant microorganisms found in the infected root canals and endodontic treatment failures $[9,10]$.

The clinical challenge to deliver irrigants into unprepared infected canal extensions; as well as the most apical infected segment recommended the use of automated agitation of irrigant in disinfection of root canal systems [7]. So the present study evaluated the antibacterial effect of activated agitation of diode laser, sonic and side-vented needle with three types of irrigants; Chlorhexidine, AgNps, and distilled water in infected oval root canal with E faecalis. Chlorhexidine (CHX) was selected in the present study as it has a broadspectrum antimicrobial effect and kills E. faecalis in the dentinal tubules. [9]. .as well as AgNps exhibit potential antibacterial activity and does not allow to develop resistance [11] Positively charged AgNps interact with the negatively charged bacterial cell walls, adhere, and penetrate into the bacterial cell leading to the loss of cell wall integrity and permeability [ 12-17].

Diode laser induced cavitation and side vented needle non laminar streaming probably provided better mechanical turbulence to penetrate infected dentin and effectively carry away the microorganisms than acoustic streaming by vibrating inserts of endoactivator [18-20].

In the present study the lasing protocol favored the disinfection of the root canal. Through limited studies existed specially on $810 \mathrm{~nm}$ diode laser; generally, diode agitation seems promising $[6,18]$. Agitation of AgNps by $810 \mathrm{~nm}$ diode laser I watt for $50 \mathrm{sec}$ improved E. faecalis eradication compared to sonic or needle agitation. Using $10 \mathrm{sec}$ continuous $810 \mathrm{~nm}$ diode laser which repeated five times for agitation of AgNps improved e faecalis eradication by $78.05 \%$ however inadequacy of diode laser to remove more percentage of bacteria may be due to using of low output power (1 watt) which is in accordance with other studies [21-26].

Sonic agitation produced bactericidal effect in the present study probably due to oscillating movement which allow hydrodynamic circulation of the irrigant. A reduced antibacterial efficiency of sonic compared with other techniques may be due to the greater displacement amplitude of the small vigorously vibrating polymer tip, also due

To weakened. Currents, impeding microstreaming and irrigant activation in apical part of the root beyond the vibrating tip [27-29].

In the present study, laser activated agitation was more efficient than endoactivator 
[18 ].Endoactivator in the present study was less efficient than needle agitation this may be due to vacuum and remove of irrigant before replenishing [30 ].Side-vented needle agitation came after laser and better than sonic as vertical up and down movements of the needle allowed distributing the localized high dynamic flow at the side exit along the oval canal allowed effective reflux of irrigant coronally as previously reported [30] .

The enhancing effect of $810 \mathrm{~nm}$ diode laser agitation in disinfection of oval canals can be complemented by a further study to evaluate other different protocols in canal disinfection with different irrigant and providing better bactericidal effect.

\section{CONCLUSIONS}

Under the condition of the present study; the results reinforced that laser activation is a useful adjunct, $810 \mathrm{~nm}$ diode laser agitation of AgNps and chlorhexidine was more effective in disinfection of oval root canals than endoactivator and side vented needle techniques.

\section{REFERENCES}

1. Halkai KR, Mudda JA, Shivanna V, Rathod V, Halkai R. Antibacterial efficacy of biosynthesized silver nanoparticles against enterococcus faecalis biofilm: an in vitro study. Contemp Clin Dent. 2018;9(2):237 41. doi:10.4103/ ccd.ccd_828_17.

2. de Almeida J, Cechella BC, Bernardi AV, de Lima Pimenta A, Felippe WT. Effectiveness of nanoparticles solutions and conventional endodontic irrigants against Enterococcus faecalis biofilm. Indian J Dent Res. 2018;29(3):347-31. doi:10.4103/ijdr.IJDR 63415.

3. Mahendra A, Koul M, Upadhyay V, Dwivedi R. Comparative evaluation of antimicrobial substantivity of different concentrations of chlorhexidine as a root canal irrigant: An in vitro study. J Oral Biol Craniofac Res. 2014;4(3):181-5. doi:10.1016/j.jobcr.2014.11.005.

4. González-Luna P,Martínez-Castañón GA, Zavala-Alonso NV, Marin NP, Niño-Martínez N, Morán-Martínez J. et al. Bactericide effect of silver nanoparticles as a final irrigation agent in endodontics on Enterococcus faecalis: an x vivo study. J Nanomaterials. 2016. Article ID 7597295. doi: http://dx.doi.org/10.1155/2016/7597295.

5. Arslan H, Ayrancı LB, Karatas E, Topçuoğlu HS, Yavuz MS, Kesim B. Effect of agitation of EDTA with 808-nanometer diode laser on removal of smear layer. J Endod. 2013;39(12):1589-92. doi:10.1016/j.joen.2013.07.016.
6. Asnaashari M, Godiny M, Azari-Marhabi S, Tabatabaei FS, Barati M. Comparison of the antibacterial effect of $810 \mathrm{~nm}$ diode laser and photodynamic therapy in reducing the microbial flora of root canal in endodontic retreatment in patients with periradicular lesions. J Lasers Med Sci. 2016;7(2):99-104. doi:10.15171/jlms.2016.17.

7. Akman M, Akbulut MB, Aydinbelge HA, Belli S. Comparison of different irrigation activation regimens and conventional irrigation techniques for the removal of modified triple antibiotic paste from root canals. J Endod. 2015;41(5):720-4. doi:10.1016/j.joen.2015.01.001.

8. Khalap ND, Kokate S, Hegde V. Ultrasonic versus sonic activation of the final irrigant in root canals instrumented with rotary/reciprocating files: an in-vitro scanning electron microscopy analysis. J Conserv Dent. 2016;19(4):368-72. doi:10.4103/0972-0707.186451.

9. Additive effect of a diode laser on the antibacterial activity of $2.5 \%$ $\mathrm{NaOCl}, 2 \% \mathrm{CHX}$ and MTAD against Enterococcus faecalis contaminating root canals: an in vitro study. J Oral Sci. 2011;53(3):355-60. doi:10.2334/ josnusd.53.355.

10. Wu D, Fan W, Kishen A, Gutmann JL, Fan B. Evaluation of the antibacterial efficacy of silver nanoparticles against Enterococcus faecalis biofilm. J Endod. 2014;40(2):285-90. doi:10.1016/j.joen.2013.08.022.

11. Afkhami F, Akbari S, Chiniforush N. Entrococcus faecalis Elimination in Root Canals Using Silver Nanoparticles, Photodynamic Therapy, Diode Laser, or Laser-activated Nanoparticles: An In Vitro Study. J Endod. 2017;43(2):279-82. doi:10.1016/j.joen.2016.08.029.

12. Mahendra A, Koul M, Upadhyay V, Dwivedi R. Comparative evaluation of antimicrobial substantivity of different concentrations of chlorhexidine as a root canal irrigant: an in vitro study. J Oral Biol Craniofac Res. 2014;4(3):181-5. doi:10.1016/j.jobcr.2014.11.005.

13. Kangarlou A, Tashfam B, Naseri M, Dianat 0, Taheri S. In vitro comparison of antibacterial efficacy of a new irrigation solution containing nanosilver with sodium doi: https://doi.org/10.22037/jds.v31i1.28638.

14. Melo MA, Cheng L, Zhang K, Weir MD, Rodrigues LK, Xu HH. Novel dental adhesives containing nanoparticles of silver and amorphous calcium phosphate. Dent Mater. 2013;29(2):199-210. doi:10.1016/j.dental.2012.10.005.

15. Javidi M, Afkhami F, Zarei M, Ghazvini K, Rajabi O. Efficacy of a combined nanoparticulate/calcium hydroxide root canal medication on elimination of Enterococcus faecalis. Aust Endod J. 2014;40(2):61-5. doi:10.1111/ aej.12028.

16. Rai MK, Deshmukh SD, Ingle AP, Gade AK. Silver nanoparticles: the powerful nanoweapon against multidrug-resistant bacteria. J Appl Microbiol. 2012;112(5):841-52. doi:10.1111/j.1365-2672.2012.05253.x.

17. Lu Z, Rong K, Li J, Yang H, Chen R. Size-dependent antibacterial activities of silver nanoparticles against oral anaerobic pathogenic bacteria. J Mater Sci Mater Med. 2013;24(6):1465-71. doi:10.1007/s10856-013-4894-5.

18. Bago I,Plečko V, Gabrić Pandurić D, SchauperIZ, Baraba A, Anić l. Antimicrobial efficacy of a high-power diode laser, photo-activated disinfection, conventional and sonic activated irrigation during root canal treatment. Int Endod J. 2013;46(4):339-47. doi:10.1111/.j.13652591.2012.02120.x.

19. Mathew J, Emil J, Paulaian B, John B, Raja J, Mathew J. Viability and antibacterial efficacy of four root canal disinfection techniques evaluated using confocal laser scanning microscopy. J Conserv Dent. 2014;17(5):4448. doi:10.4103/0972-0707.139833.

20. Mohammadi Z, Giardino L, Mombeinipour A. Antibacterial substantivity of a new antibiotic-based endodontic irrigation solution. Aust Endod J. 2012;38(1):26-30. doi:10.1111/j.1747-4477.2010.00263.x. 
21. de Almeida J, Cechella BC, Bernardi AV, de Lima Pimenta A, Felippe WT. Effectiveness of nanoparticles solutions and conventional endodontic irrigants against Enterococcus faecalis biofilm. Indian J Dent Res. 2018;29(3):347-51. doi:10.4103/ijdr.IJDR 63415.

22. Rodrigues CT, de Andrade FB, de Vasconcelos LRSM, et al. Antibacterial properties of silver nanoparticles as a root canal irrigant against Enterococcus faecalis biofilm and infected dentinal tubules. Int Endod J. 2018;51(8):901-11. doi:10.1111/iej.12904 .

23. Castelo-Baz P, Martin-Biedma B, Ruiz-Pinon M, Rivas-Mundina B, Bahillo J, Seoane-Prado R, et al. Combined sodium hypochlorite and 940 NM diode laser treatment against mature E. facials boxfuls in-vitro. Lasers Med. 2012;3(3):116-21. doi: https://doi.org/10.22037/jIms.v3i3.3074.

24. Borges CC, Estrela C, Lopes FC, Palma-Dibb RG, Pecora JD, Estrela CRA, et al. Effect of different diode laser wavelengths on root dentin decontamination infected with Enterococcus faecalis. J Photochem Photobiol B. 2017;176:1-8. doi:10.1016/j.jphotobiol.2017.09.009.

25. Mithra NH, Krishna RS, Shishir S, Veenna SA. Comparative evaluation of bactericidal effects on Enterococcus faecalis using diode laser irradiation sodium hypochlorite and chlorhexidine gluconate irrigation"- an in vitro study. Oral Health Dent Manag. 2013;12(3):145-50.

26. Portenier I, Waltimo TMT, Haapasalo M. Enterococcus faecalis-the root canal survivor and star in post-treatment disease. Endod Topics. 2003; 6(1):135-59.
27. Johnson M, Sidow SJ, Looney SW, Lindsey K, Niu LN, Tay FR. Canal and isthmus debridement efficacy using a sonic irrigation technique in a closed-canal system. J Endod. 2012;38(9):1265-8. doi:10.1016/j. joen.2012.05.009.

28. Zeng C, Willison J, Meghil MM, Bergeron BE, Cutler CW, Tay FR, et al. Zeng C, Willison J, Meghil MM, et al. Antibacterial efficacy of an endodontic sonic-powered irrigation system: an in vitro study. J Dent. 2018;75:105-112. doi:10.1016/j.jdent.2018.06.003.

29. Forghani M, Afshari E, Parisay I, Garajian R. Effect of a passive sonic irrigation system on elimination of Enterococcus faecalis from root canal systems of primary teeth, using different concentrations of sodium hypochlorite: an in vitro evaluation. J Dent Res Dent Clin Dent Prospects. 2017;11(3):177-82. doi:10.15171/joddd.2017.032

30. Shen Y, Stojicic S, Qian W, Olsen I, Haapasalo M. The synergistic antimicrobial effect by mechanical agitation and two chlorhexidine preparations on biofilm bacteria. J Endod. 2010;36(1):100-4. doi:10.1016/j. joen.2009.09.018.

31. Chatterjee R, Venugopal P, Jyothi KN, Jayashankar CM, Anil Kumar S, Sarath Kumar P.Effect of sonic agitation, manual dynamic agitation on removal of Enterococcus faecalis biofilm. Saudi Endod J. 2015; 5(2):125-8. doi: 10.4103/1658-5984.155451. 
$\mathrm{d}$ is suitable for predicting the chronological age, whereas Fishman method is accurate to estimate the skeletal maturity stages, since it represents a clear and easily identified SMI stages [11].

\section{Study limitation}

The regression models suggested in this study need to be validated.

\section{CONCLUSIONS}

Within the limits of this study results, it is concluded that there is a strong correlation between chronological age and skeletal age estimated by Fishman method and dental age estimated by Nolla method. Yemeni children are delayed in skeletal maturity and dental development when compared to Fishman and Nolla age standards. Chronological age of Yemeni children is unsuitable dependent timing for orthodontic intervention. Skeletal age remains essential for clinical orthodontic practices, while dental age estimated by Nolla method is a helpful mean for prediction of unknown chronological age for Yemeni boys and girls aged between 13 and 16 years for civil and forensic purposes.

\section{Financial or other competing interests:} None.

Financial grants: The study work was self-funded.

Acknowledgments: Our thanks to the principals, parents and children of all schools participated in the study sample. Worm greetings to Dr. Mohammed Nasser Alhaj for his assistance.

\section{REFERENCES}

1. Krailassiri S, Anuwongnukroh N, Dechkunakorn S. Relationships between dental calcification stages and skeletal maturity indicators in Thai individuals. Angle Orthod. 2002;72(2):155-66. doi:10.1043/00033219(2002)072«0155:RBDCSA»2.0.C0;2

2. Willems $G$. A review of the most commonly used dental age estimation techniques. J Forensic Odontostomatol. 2001;19(1):9-17.

3. Nolla CM. The development of the permanent teeth. J Dent Child.
1960:27:254-66.

4. Fishman LS. Radiographic evaluation of skeletal maturation. A clinically oriented method based on hand-wrist films. Angle Orthod. 1982;52(2):88112. doi:10.1043/0003-3219(1982)052«0088:REOSM»2.0.C0;2

5.

6. 5. Kiran S, Sharma VP, Tandon P, Tikku T, Verma S, Srivastava K. To establish the validity of dental age assessment using Nolla's method on comparing with skeletal age assessed by hand-wrist radiographs. J Orthod Res. 2013;1(1):11-5.

7.

8. 6. Soegiharto BM, Cunningham SJ, Moles DR. Skeletal maturation in Indonesian and white children assessed with hand-wrist and cervical vertebrae methods. Am J Orthod Dentofacial Orthop. 2008;134(2):217-26. doi:10.1016/j.ajodo.2006.07.037

9. Flores-Mir C, Nebbe B, Major PW. Use of skeletal maturation based on hand-wrist radiographic analysis as a predictor of facial growth: a systematic review. Angle Orthod. 2004;74(1):118-24. doi:10.1043/00033219(2004)074«0118:UOSMBO»2.0.C0;2

10. Soegiharto BM, Moles DR, Cunningham SJ. Discriminatory ability of the skeletal maturation index and the cervical vertebrae maturation index in detecting peak pubertal growth in Indonesian and white subjects with receiver operating characteristics analysis. Am J Orthod Dentofacial Orthop. 2008;134(2):227-37. doi:10.1016/j.ajodo.2006.09.062

11. Saadé A, Baron P, Noujeim Z, Azar D. Dental and skeletal age estimations in lebanese children: a retrospective cross-sectional Study. J Int Soc Prev Community Dent. 2017;7(3):90-7. doi:10.4103/jispcd.JISPCD_139_17.

12. Camacho-Basallo P, Yáñez-Vico RM, Solano-Reina E, Iglesias-Linares A. Five radiographic methods for assessing skeletal maturity in a Spanish population: is there a correlation?. Acta Odontol Scand. 2017;75(2):106-12. doi:10.1080/00016357.2016.1265145.

13. Mohammed RB, Kalyan VS, Tircouveluri S, Vegesna GC, Chirla A, Varma DM. The reliability of Fishman method of skeletal maturation for age estimation in children of South Indian population. J Nat Sci Biol Med. 2014;5(2):297-302. doi:10.4103/0976-9668.136170.

14. Kırzıoğlu Z, Ceyhan D. Accuracy of different dental age estimation methods on Turkish children. Forensic Sci Int. 2012;216(1-3):61-7. doi:10.1016/j.forsciint.2011.08.018.

15. Nur B, Kusgoz A, Bayram M, Celikoglu M, Nur M, Kayipmaz S, et al. Validity of demirjian and nolla methods for dental age estimation for Northeastern Turkish children aged 5-16 years old. Med Oral Patol Oral Cir Bucal. 2012;17(5):e871-e7. Published 2012 Sep 1. doi:10.4317/medoral.18034.

16. Sinha S, Umapathy D, Shashikanth MC, Misra N, Mehra A, Singh AK. Dental age estimation by Demirjian's and Nolla's method: A comparative study among children attending a dental college in Lucknow (UP). J Indian Acad Oral Med Radiol. 2014;26(3):279-86. doi: 10.4103/0972-1363.145005.

17. Martínez Gutiérrez VM, Ortega-Pertuz Al. Comparison of Nolla, Demirjian and Moorrees methods for dental age calculation for forensic purposes. Rev Odont Mex. 2017;21(3):155-64. https://doi.org/10.1016/j. rodmex.2017.09.011.

18. Hegde S, Patodia A, Dixit U. A comparison of the validity of the Demirjian, Willems, Nolla and Häävikko methods in determination of chronological age of 5-15 year-old Indian children. J Forensic Leg Med. 2017;50:49-57. doi:10.1016/j.jflm.2017.07.007.

19. Melo M, Ata-Ali J. Accuracy of the estimation of dental age in comparison 
with chronological age in a Spanish sample of 2641 living subjects using the Demirjian and Nolla methods. Forensic Sci Int. 2017;270:276.e1-276.e7. doi:10.1016/j.forsciint.2016.10.001

20. Altunsoy M, Nur BG, Akkemik 0, Evren 0, Evcil MS. Dental age assessment: validity of the Nolla method in a group of western Turkish children. Marmara Dent J. 2013;1(2):49-52.

21. Bala M, Pathak A, Jain RL. Assessment of skeletal age using MP3 and hand-wrist radiographs and its correlation with dental and chronological ages in children. J Indian Soc Pedod Prev Dent. 2010;28(2):95-9. doi:10.4103/0970-4388.66746.

22. Kurita LM, Menezes AV, Casanova MS, Haiter-Neto F. Dental maturity as an indicator of chronological age: radiographic assessment of dental age in a Brazilian population. J Appl Oral Sci. 2007;15(2):99-104. doi:10.1590/ s1678-77572007000200005

23. Liversidge HM. Interpreting group differences using Demirjian's dental maturity method. Forensic Sci Int. 2010;201(1-3):95-101. doi:10.1016/j. forsciint.2010.02.032

24. Murata M, Hibi I. Nutrition and the secular trend of growth. Horm Res. 1992;38 Suppl 1:89-96. doi:10.1159/000182578.
25. Liversidge HM, Speechly T, Hector MP. Dental maturation in British children: are Demirjian's standards applicable? Int J Paediatr Dent 1999;9(4):263-9. doi:10.1111/j.1365-263x.1999.00144.x.

26. Ozer BK. Growth reference centiles and secular changes in Turkish children and adolescents. Econ Hum Biol. 2007;5(2):280-301. doi:10.1016/j. ehb.2007.03.007.

27. Akkaya N, Yilanci HÖ, Göksülük D. Applicability of Demirjian’s four methods and Willems method for age estimation in a sample of Turkish children. Leg Med (Tokyo). 2015;17(5):355-9. doi:10.1016/j. legalmed.2015.04.003

28. Garn SM, Lewis AB, Kerewsky RS. Genetic, nutritional, and maturational correlates of dental development. J Dent Res. 1965;44(1):228-42. doi:10.117 7/00220345650440011901.

29. Chaillet N, Nyström M, Kataja M, Demirjian A. Dental maturity curves in Finnish children: Demirilan's method revisited and polynomial functions for age estimation. J Forensic Sci. 2004;49(6):1324-1331.

Prof. Latifa Mohamed Abdelgawad

(Corresponding address)

Medical Laser Applications department, National Institute of Laser Enhanced Science,

Cairo University, Giza ,Egypt.

Date submitted: 2019 Dec 12

E-mail: lattifa@niles.edu.eg 